\title{
SC-535, a Novel Oral Multikinase Inhibitor, Showed Potent Antitumor Activity in Human Melanoma Models
}

\author{
Xin Chen ${ }^{a}$ Pan Jia Hui-Wen Yang Ling-Ling Yang Shu Zhou Lei Zhong \\ Shuang Ma Xiao-Yu Fu Chan Zhou Guo-Bo Li Ming-Wu Zheng \\ Yu-Quan Wei Sheng-Yong Yang
}

State Key Laboratory of Biotherapy and Cancer Center, West China Hospital, West China Medical

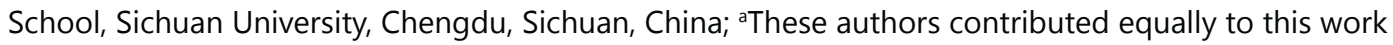

\author{
Key Words \\ $\mathrm{SC}-535 \cdot \mathrm{BRAF} \cdot \mathrm{CRAF} \cdot \mathrm{G} 2 / \mathrm{M}$ phase cell cycle arrest $\bullet$ Antiangiogenesis
}

\begin{abstract}
Background: Melanoma is considered as one of the most aggressive and deadliest cancers and current targeted therapies of melanoma often suffer limited efficacy or drug resistance. Discovery of novel multikinase inhibitors as anti-melanoma drug candidates is still needed. Methods: In this investigation, we assessed the in vitro and in vivo anti-melanoma activities of SC-535, which is a novel small molecule multikinase inhibitor discovered by us recently. We analyzed inhibitory effects of SC-535 on various melanoma cell lines and human umbilical vascular endothelial cells (HUVEC) in vitro. Tumor xenografts in athymic mice were used to examine the in vivo activity of SC-535. Results: SC-535 could efficiently inhibit vascular endothelial growth factor receptor (VEGFR) 1/2/3, B-RAF, and C-RAF kinases. It showed significant antiangiogenic potencies both in vitro and in vivo and considerable anti-proliferative ability against several melanoma cell lines. Oral administration of SC-535 resulted in dose-dependent suppression of tumor growth in WM2664 and C32 xenograft mouse models. Studies of mechanisms of action indicated that SC-535 suppressed the tumor angiogenesis and induced G2/M phase cell cycle arrest in human melanoma cells. SC-535 possesses favorable pharmacokinetic properties. Conclusion: All of these results support SC535 as a potential candidate for clinical studies in patients with melanoma.
\end{abstract}




\section{Cellular Physiology and Biochemistry}

Cell Physiol Biochem 2013;32:138-153

DOI: $10.1159 / 000350123$

online: July 12, 2013

C) 2013 S. Karger AG, Basel

www.karger.com/cpb

\section{Introduction}

Melanoma, a malignant tumor of skin cancer, is often considered as one of the most aggressive and deadliest cancers. The incidence rate of melanoma was reported to keep increasing over the past decades [1]. The grim situation incited a mass of investigations that focused on understanding of pathogenesis of melanoma and discovery of drugs targeting melanoma [2,3]. Although the pathogenesis of melanoma is far from being fully understood, it has been commonly accepted that the mitogen-activated protein kinase (MAPK) signaling pathway is greatly involved in the development of melanoma [4]. Sustaining activation of MAPK is one of the typical characteristics of melanomas, and mutations of RAF, which is one of the key components of MAPK signaling pathway, are a major villain [5]. The RAF family of proteins includes three isoforms: ARAF, BRAF, and CRAF. While each isoform plays a role in the MAPK pathway, BRAF is one of the most important activators of MAPK signaling $[6,7]$. Activating mutations in BRAF have been found in approximate $50 \%$ of melanomas [1], and the most frequent BRAF mutation is the substitution of Val 600 residue by Glu (V600E) that leads to constitutive activation of BRAF independent of Ras activity [8]. Therefore BRAF has currently been thought as one of the most important therapeutic targets for the treatment of melanomas $[6,9]$.

Meanwhile, similar to other solid tumors, melanomas are highly vascular tumors that frequently overexpress angiogenic factors $[10,11]$. VEGF is one of the main fundamental regulating factors of tumor angiogenesis and its expression is an independent predictive factor of overall survival (OS) in melanomas $[12,13]$. These suggest the plausibility of targeting VEGF mediated tumor angiogenesis clinically [14]. Nevertheless, such antiangiogenic strategies are less well studied in melanomas compared with some other solid tumor types. Although exact reasons responsible for this situation are unknown, the unimpressive clinical efficacy of sorafenib, which is a famous blocker of VEGF signaling, may have some influence [15-17]. However, VEGF signaling remains an attractive drug target and new inhibitors such as axitinib and lenvatinib have begun to show promising clinical efficacy in the treatment of melanomas $[18,19]$.

It is reasonable to hypothesize that multi-targeted agents that can simultaneously suppress the tumor angiogenesis and block the MAPK signaling may benefit the therapeutic efficacy and reduce the risk of drug resistance [20, 21]. SC-535, 1-(4-(1H-pyrazolo[3,4-d] pyrimidin-4-yloxy)phenyl)-3-(4-chloro-3-(trifluoromethyl)phenyl)urea (Fig. 1A), is a multi-targeted kinase inhibitor discovered by us recently [22]. This compound can efficiently inhibit VEGFR2, BRAF ${ }^{\mathrm{V} 600 \mathrm{E}}$, wild-type BRAF (BRAFWT), and CRAF, as well as other kinases, in which VEGFR2 is associated with angiogenesis, and $\mathrm{BRAF}^{\mathrm{V} 600 \mathrm{E}}$, $\mathrm{BRAF}^{\mathrm{WT}}$, and CRAF are key components of the MAPK signaling pathway. SC-535 showed considerable potency against melanoma both in vitro and in vivo. In this account, we report the assessment of anti-melanoma activities of SC-535 in vitro and in vivo, as well as its mechanisms of action.

\section{Materials and Methods}

\section{Cell lines}

Human melanoma cells A2058, WM2664, CHL-1, HT-144, C32, SK-MEL-28, WM115, and Malme-3M, as well as murine colon cancer cells CT-26, were obtained from American Type Culture Collection (ATCC, Rockville, MD, USA). Human melanoma cell line A375 and A875 were obtained from Cell Culture Center of the Institute of Basic Medical Sciences of Chinese Academy of Medical Sciences and School of Basic Medicine of Peking Union Medical College (Beijing, China). All of them were grown in Dulbecco's modified Eagle's medium (DMEM) supplemented with 10\% fetal bovine serum (FBS; Gibco, Eggenstein, Germany), 100 units/ $\mathrm{ml}$ penicillin (Sigma-Aldrich) and streptomycin (Sigma-Aldrich), and maintained in the $37^{\circ} \mathrm{C}$ incubator with a humidified 5\% CO2 atmosphere. Human umbilical vein endothelial cells (HUVEC) were isolated from human umbilical cord veins using a standard procedure as previously described [23] and grown in EBM-2 medium with SingleQuots ${ }^{\mathrm{TM}}$ (Lonza, Walkersville, MD, USA) containing VEGF and other growth factors. 


\section{Cellular Physiology and Biochemistry}

Fig. 1. The chemical structure of SC-535 and the dose-response relationships in cell growth inhibition assays. (A) The chemical structure of SC-535. (B) Cells were treated with SC-535 for $72 \mathrm{~h}$ and cell viability was evaluated by MTT assay. Every experiment was tested in triplicate and repeated 3 times, and the data are presented as the mean \pm SEM, $(n=9)$.

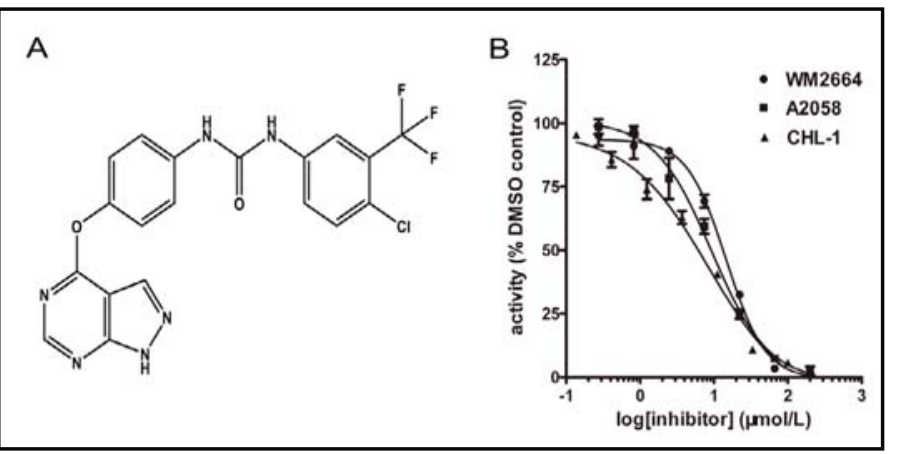

Preparation of SC-535

SC-535 was synthesized in the State Key Laboratory of Biotherapy, Sichuan University (Sichuan, China). Sorafenib was obtained from commercial sources. For all in vitro assays and zebrafish assays, SC-535 was prepared initially as a $100 \mathrm{mM}$ stock solution in dimethyl sulfoxide (DMSO). Stock solution was diluted in the relevant assay media and $0.1 \%$ DMSO served as a vehicle control. For in vivo studies, SC-535 was dissolved in 25\% (v/v) aqueous Cremophor EL/ethanol (50:50; Cremophor EL, 100\% ethyl alcohol; Sigma, Saint Louis, MO, USA). Sorafenib was dissolved in the same solvent.

\section{Kinase inhibition assays}

Kinase inhibitory activities were measured using radiometric assays provided by Kinase Profiler Service (Millipore, Billerica, MA USA).

\section{Cell growth inhibition assays}

Anti-proliferative activities of compounds were measured using 3-(4,5)-dimethylthiahiazo(-z-y1)-3,5-di-phenytetrazoliumromide (MTT) assays and EdU incorporation assays as previously described [24]. Various cells $\left(2 \sim 8 \times 10^{3}\right.$ cells/well) were treated with indicated concentrations of SC-535 for $72 \mathrm{~h}$. Each assay was performed in 3 replicates. The $\mathrm{IC}_{50}$ values were calculated by GraphPad Prism 5.01 software (Prism Statistical Software). EdU is a thymidine analogue used for marking the proliferating cells, which can insert into replicating DNA during S phase [25]. HUVEC growing in 96 -well plates $\left(1 \times 10^{4}\right.$ cells/well $)$ were treated with SC-535 for $24 \mathrm{~h}$. Then, the proliferative cells were assayed with an EdU-Apollo ${ }^{\circledR 567}$ (RiboBio, Guangzhou, China) DNA Proliferation Detection kit according to the manufacturer's instructions. Images were taken by High Content Screening and Analysis (Thermo Fisher Cellomics).

\section{Cell cycle analysis by flow cytometry (FCM)}

FCM assays were carried out as described previously [26]. FCM assays were adopted to examine the cell cycle status with and without SC-535 treated. Cell culture and drug treatment with different concentrations were done as described above. Cells were collected and washed with cold PBS. Then $0.4 \mathrm{ml}$ hypotonic fluorochrome solution containing $50 \mu \mathrm{g} / \mathrm{ml}$ propidium iodide (PI) in $0.1 \%$ sodium citrate plus $0.1 \%$ Triton $\mathrm{X}-100$ was added to cells and 40000 cells were analyzed by FCM (ESP Elite, Beckman-Coulter, Miami, FL, USA).

\section{Wound healing assay}

Monolayer HUVEC were wounded by scratching with pipette tips and washed with EBM-2 medium (without growth factors). Fresh EGM-2 medium (containing various growth factors) containing vehicle or different concentrations of SC-535 was added to the scratched monolayers. Images were taken by fluorescence microscope (Carl Zeiss Microimaging Inc.) after $24 \mathrm{~h}$.

\section{Transwell invasion assay}

Invasion assays were carried out as described previously [27]. First, the filter of the transwell plate (BD Biosciences, Franklin Lakes, NJ, USA) was coated with $50 \mu \mathrm{l}$ Matrigel (BD Biosciences, Franklin Lakes, $\mathrm{NJ}$, USA). After polymerizing at $37^{\circ} \mathrm{C}$ for $30 \mathrm{~min}$, the bottom chambers were filled with $800 \mu \mathrm{LGM}-2$ medium and the top chambers were seeded with $200 \mu \mathrm{l} \mathrm{EBM}-2$ medium and $2 \times 10^{4}$ HUVEC. The top chamber contained vehicle or various concentrations of SC-535. Cells were allowed to migrate for $24 \mathrm{~h}$. Nonmigrated 


\section{Cellular Physiology and Biochemistry}

Cell Physiol Biochem 2013;32:138-153

DOI: $10.1159 / 000350123$

Published online: July 12,2013

(C) 2013 S. Karger AG, Basel

www.karger.com/cpb

cells were erased with a cotton swab, and migrated cells were fixed with $100 \%$ methanol for 30 min and then stained with $0.05 \%$ crystal violet. The cells were photographed under a light microscope.

\section{Tube formation assays}

The tube formation assays were performed as described previously [28]. First, the 96-well plate (Corning, USA) was coated with $50 \mu$ l Matrigel. After polymerizing at $37{ }^{\circ} \mathrm{C}$ for $30 \mathrm{~min}$, HUVEC suspended in EGM-2 medium were seeded in the plate. They were then treated with SC-535, or vehicle control. After $8 \mathrm{~h}$, cells were photographed with a digital camera attached to an inverted microscope.

\section{Western blot analysis}

In assays for determining the inhibitory effects of SC-535 on VEGFR2-dependent signaling cascade, HUVEC were serum starved overnight, and then incubated with SC-535 for $2 \mathrm{~h}$ and stimulated by VEGF ( 50 $\mathrm{ng} / \mathrm{ml}$ ) for $10 \mathrm{~min}$. Cells were lysed with ripa buffer (Biotime) containing $0.1 \%$ PMSF and $1 \%$ proteinase inhibitor cocktail (Sigma, Saint Louis, MO, USA). Protein concentrations were determined using Bio-read Protein Assay Kit (Bio-Rad, USA) and equalized before loading. Forty micrograms of cellular protein from each sample was applied to 10\% SDS-PAGE gels and probed with specific antibodies (Cell Signaling Technology, USA; Abcam Biocamicals, UK). In assays for examining the mechanisms of action of SC-535 on the melanoma cells, WM2664 cells were incubated with SC-535 for $24 \mathrm{~h}$. Expression levels or activation status of MAPK signaling proteins, apoptosis associated proteins, and cell cycle related proteins were detected in WM2664 melanoma cells.

\section{In vivo antiangiogenesis assays in transgenic zebrafish}

The FLK-1 promoter EGFP transgenic zebrafish (FLK-1:EGFP) was used to investigate the in vivo antiangiogenic activity. 30 embryos per experimental group were used in our study, and each experiment was performed in 3 replicates. Embryos placed in 24-well plates were maintained in Holtfreter's solution in a humidified incubator at $28.5^{\circ} \mathrm{C}$. Zebrafish embryos were incubated overnight with $1.25 \mu \mathrm{M}, 2.5 \mu \mathrm{M}$ and 5 $\mu \mathrm{M}$ SC-535 or vehicle from $15 \mathrm{~h}$ post-fertilization (hpf) until $31 \mathrm{hpf}$. At $30 \mathrm{hpf}$, zebrafish were anesthetized with $0.01 \%$ tricaine and imaged under the fluorescence microscope (Carl Zeiss Microimaging Inc.) equipped with an AxioCam MRc5 digital CCD camera (Carl Zeiss Microimaging Inc.)

\section{Alginate-encapsulate tumor cell assay}

An alginate-encapsulate assay was performed as described [29]. Briefly, alginate beads containing $5 \times 10^{4}$ tumor cells per bead were formed and implanted s.c. into both dorsal sides of the athymic mice. Then mice were orally gavaged with SC-535 at $40 \mathrm{mg} / \mathrm{kg}, 20 \mathrm{mg} / \mathrm{kg}$ or vehicle once a day for 14 day (d). At the end of experiment, $0.1 \mathrm{ml}$ of 2\% FITC-dextran solution (Sigma, Saint Louis, MO, USA) was injected i.v. into the lateral tail vein of mice. After being exposed surgically, alginate beads were removed and photographed within $20 \mathrm{~min}$. And the uptake of FITC-dextran was detected as described previously [29].

\section{Xenograft mouse models}

Animal studies were conducted in conformity with institutional guide for the care and use of laboratory animals. All mouse protocols were approved by the Animal Care and Use Committee of Sichuan University (Chengdu, Sichuan, China). Six-week-old female athymic (nu/nu) mice were obtained from Chinese Academy of Medical Science (Beijing, China). WM2664 and C32 tumors were established by s.c. injection of $1 \times 10^{7}$ cells, respectively. After about two weeks, mice bearing tumors around $150-200 \mathrm{~mm}^{3}$ were selected and randomized into treatment groups ( 6 mice per group). The animals were orally gavaged daily with SC535 , sorafenib and vehicle control. Tumor length and width were measured every three days, and tumor volume (TV) was calculated using the following expression: TV $=$ length $\times$ wid $^{2} \times 0.5$. Solid tumors were removed and processed to immunohistochemical analysis when the mice were administrated after 10 days, and the tumors were fixed in formalin followed by paraffin-embedded. At the end of experiment, mice were sacrificed.

\section{Immunohistochemistry}

To investigate the tumor proliferation inhibition potencies of SC-535, we examined the proliferous cells by immunostaining with Ki67 (Thermo Fisher Scientific, Fremont, CA) in paraffin-embedded tumors. 
Chen et al.: SC-535, a Multikinase Inhibitor, Anti-Melanoma

Table 1. Kinase inhibition profile for SC-535 against a panel of selected protein kinases. *Kd values

\begin{tabular}{lccc}
\hline Kinase & $\mathrm{IC}_{50}(\mu \mathrm{M})$ & Kinase & $\mathrm{IC}_{50}(\mu \mathrm{M})$ \\
\hline VEGFR1(Flt1) & 0.012 & CHK2 & $>10$ \\
VEGFR2 & 0.012 & CHEK1 & $>10$ \\
VEGFR3(Flt4) & 0.017 & CTK & $>10$ \\
Flt3 & 0.039 & DLK & $>10$ \\
*B-RafV600E $^{*}$ *-Raf & 0.061 & DMPK & $>10$ \\
C-Raf & 0.072 & EGFR & $>10$ \\
PDGFR $\alpha$ & 0.072 & ErBB2 & $>10$ \\
PDGFR $\beta$ & 0.223 & ErBB4 & $>10$ \\
C-Kit & 0.408 & ERK & $>10$ \\
EphA2 & 0.507 & ERN1 & $>10$ \\
FGFR2 & 1.222 & IGF-IR & $>10$ \\
Aurora-A & 1.805 & Lck & $>10$ \\
Aurora-B & $>10$ & PAK1 & $>10$ \\
Aurora-C & $>10$ & PAK2 & $>10$ \\
CAMK4 & $>10$ & PAK4 & $>10$ \\
CDK1/cyclinB & $>10$ & Pim-1 & $>10$ \\
CDK2/cyclinE & $>10$ & Plk1 & $>10$ \\
CDK7/cyclinH/MAT1 & $>10$ & Plk3 & $>10$ \\
CHK1 & $>10$ & MLK1 & $>10$ \\
\hline
\end{tabular}

To investigate whether SC-535 inhibited tumor growth by suppressing tumor angiogenesis, we examined the vessel density in tumor tissue as described previously [30]. Frozen sections of WM2664 and C32 tumor xenografts were used to determine vessel density with an anti-CD31 antibody (BD Biosciences, Franklin Lakes, NJ, USA).

\section{Pharmacokinetic assessments}

Blood from Sprague-Dawley rats with i.v. or p.o. $10 \mathrm{mg} / \mathrm{kg}$ SC-535 was collected in heparin-containing tubes and the plasma was isolated by the centrifugation. Plasma concentrations of SC-535 were determined by liquid chromatography/mass spectrometry (LC/MS).

\section{Statistical analysis}

The data are reported as the mean \pm SEM. Student's $t$-test was used to analyze differences (Prism Statistical Software). Differences were considered statistically significant if $P<0.05$.

\section{Results}

Kinase inhibition profile of SC-535

The kinase inhibition profile of SC-535 against a panel of recombinant human protein kinases is shown in Table 1. SC-535 potently inhibited VEGFR1, VEGFR2, and VEGFR3 with $\mathrm{IC}_{50}$ values of $0.012 \mu \mathrm{M}, 0.012 \mu \mathrm{M}$, and $0.017 \mu \mathrm{M}$, respectively. It could efficiently direct against B-RAF ${ }^{W T}$ and B-RAF ${ }^{\mathrm{V} 600 \mathrm{E}}$ with $\mathrm{Kd}$ values of $0.072 \mu \mathrm{M}$ and $0.061 \mu \mathrm{M}$, respectively. It also showed considerable or moderate inhibitory potency against C-RAF, FLT3, c-KIT, PDGFR $\beta$, PDGFR $\alpha$, and FGFR2 (the corresponding IC C $_{50}$ values are $0.072 \mu \mathrm{M}, 0.039 \mu \mathrm{M}, 0.507 \mu \mathrm{M}, 0.408$ $\mu \mathrm{M}, 0.223 \mu \mathrm{M}$, and $1.805 \mu \mathrm{M}$, respectively). SC-535 displayed almost no inhibitory activity against other selected 28 protein kinases. These data demonstrate that SC-535 is a multikinase inhibitor that potently inhibits VEGFR1/2/3, B-RAF, and C-RAF.

In vitro cell growth inhibitory effects of SC-535 against various melanoma cell lines

The cell growth inhibitory potencies of SC-535 against various melanoma cell lines, including those bearing $B R A F^{W T}$ and mutated $\mathrm{BRAF}$, were examined, and the results are pre- 


\section{Cellular Physiology and Biochemistry}

Cell Physiol Biochem 2013;32:138-153

\begin{tabular}{l|l}
\hline DOI: $10.1159 / 000350123$ & (C) 2013 S. Karger AG, Basel
\end{tabular}

Chen et al.: SC-535, a Multikinase Inhibitor, Anti-Melanoma

\begin{tabular}{llll}
\hline Tumor type & Tumor & Characteristics & IC $_{50}(\mu \mathrm{M})$ \\
\hline Human Malignant Melanoma & CHL-1 & RASWT, B-RAFWT & 6.46 \\
Human Malignant Melanoma & A2058 & RASWT, B-RAFv600E & 9.55 \\
Human Malignant Melanoma & WM2664 & RASWT, B-RAFv600D & 12.88 \\
Human Malignant Melanoma & HT-144 & RASWT, B-RAFv600E & 20.41 \\
Human Malignant Melanoma & A875 & RASWT, B-RAFWT & 23.52 \\
Human Malignant Melanoma & A375 & RASWT, B-RAFv600E & 29.42 \\
Human Malignant Melanoma & C32 & RASWT, B-RAFv600E & 37.61 \\
Human Malignant Melanoma & WM115 & RASWT,B-RAFv600D & 40.48 \\
Human Malignant Melanoma & SKMEL-28 & RASWT, B-RAFv60E & 71.99 \\
Human Malignant Melanoma & Malme-3M & RASWT, B-RAF6600E & 73.55 \\
\hline
\end{tabular}

Table 2. Cell growth inhibitory potencies of SC-535 against various melanoma cell lines

Table 3. Cell growth inhibitory potencies of SC535 under different conditions against HUVEC

\begin{tabular}{lc}
\hline Treatment factors & IC $_{50}(\mu \mathrm{M})$ \\
\hline VEGF $(50 \mathrm{ng} / \mathrm{ml})+1 \% \mathrm{FBS}$ & 4.63 \\
bFGF $(20 \mathrm{ng} / \mathrm{ml})+1 \% \mathrm{FBS}$ & $>10$ \\
Various Growth Factors & $>10$ \\
\hline
\end{tabular}

sented in Table 2. CHL-1, which harbors BRAF ${ }^{\mathrm{WT}}$, is the most sensitive cell line in the tested ones; the $\mathrm{IC}_{50}$ value is $6.46 \mu \mathrm{M}$ (Fig. 1B). SC-535 also showed considerable cell growth inhibitory potency against A2058 and WM2664, who bear mutated BRAF $\left(\mathrm{IC}_{50} \mathrm{~s}\right.$ : $9.55 \mu \mathrm{M}$ and $12.88 \mu \mathrm{M}$, respectively; see also Fig. 1B). For other melanoma cell lines, including HT-144, A875, A375, C32, WM115, SKMEL-28, and Malme-3M, SC-535 exhibited a weak inhibitory potency.

Effects of SC-535 on the HUVEC proliferation, migration, invasion and tube formation

To assess the antiangiogenic effects of SC-535, the antiproliferative ability of SC-535 against human umbilical vein endothelial cells (HUVEC) was first assessed by the MTT assay method. SC-535 showed a good antiproliferative activity against VEGF-stimulated HUVEC with an $\mathrm{IC}_{50}$ value of $4.63 \mu \mathrm{M}$, while it displayed no activity or very weak antiproliferative activity against bFGF- or various growth factors stimulated HUVEC at a concentration of $10 \mu \mathrm{M}$ of SC-535 (Table 3). These results indicate that SC-535 exerts its antiangiogenic function through the inhibition of VEGF signaling. Moreover, SC-535 treatment significantly decreased the number of proliferating cells (red nuclei) compared with the control in EdU incorporation assays (Fig. 2A and Fig. 2C). Then the inhibitory effects of SC-535 to HUVEC migration, invasion, and tube formation, which are indispensable for angiogenesis, were examined. In wound-healing assays, we found that SC-535 significantly inhibited the migration of HUVEC in a dose-dependent manner and the migration ability of HUVEC was inhibited by about $70 \%$ in the presence of $1.25 \mu \mathrm{M}$ of SC-535 (Fig. 2B, up panels, and Fig. 2C). In addition, in the transwell assays assessing the invasion ability of HUVEC, $5 \mu \mathrm{M}$ of SC-535 inhibited almost all invasion activities of HUVEC (Fig. 2B, middle panels, and Fig. 2C). Furthermore, we investigated the effect of SC-535 on the ability of endothelial cell tube formation. 1.25 $\mu \mathrm{M}$ of SC-535 inhibited tube formation of HUVEC by $50 \%$ and $2.5 \mu \mathrm{M}$ almost completely blocked the tube formation of HUVEC (Fig. 2B, down panels, and Fig. 2C). Taken together, these data indicate that SC-535 can inhibit angiogenesis in vitro.

SC-535 potently inhibited the activation of VEGFR2 and its downstream kinases in HUVEC

Western blot assays were performed to examine whether SC-535 could efficiently inhibit VEGFR2 and its downstream signaling in HUVEC. The results are shown in Fig. 3. From Fig. 3, we can see that $10 \mathrm{nM}$ of SC-535 significantly suppressed the phosphorylation of VEGFR2. Consistent with the suppression of VEGFR2 activation, its downstream kinases inclu- 


\section{Cellular Physiology and Biochemistry}

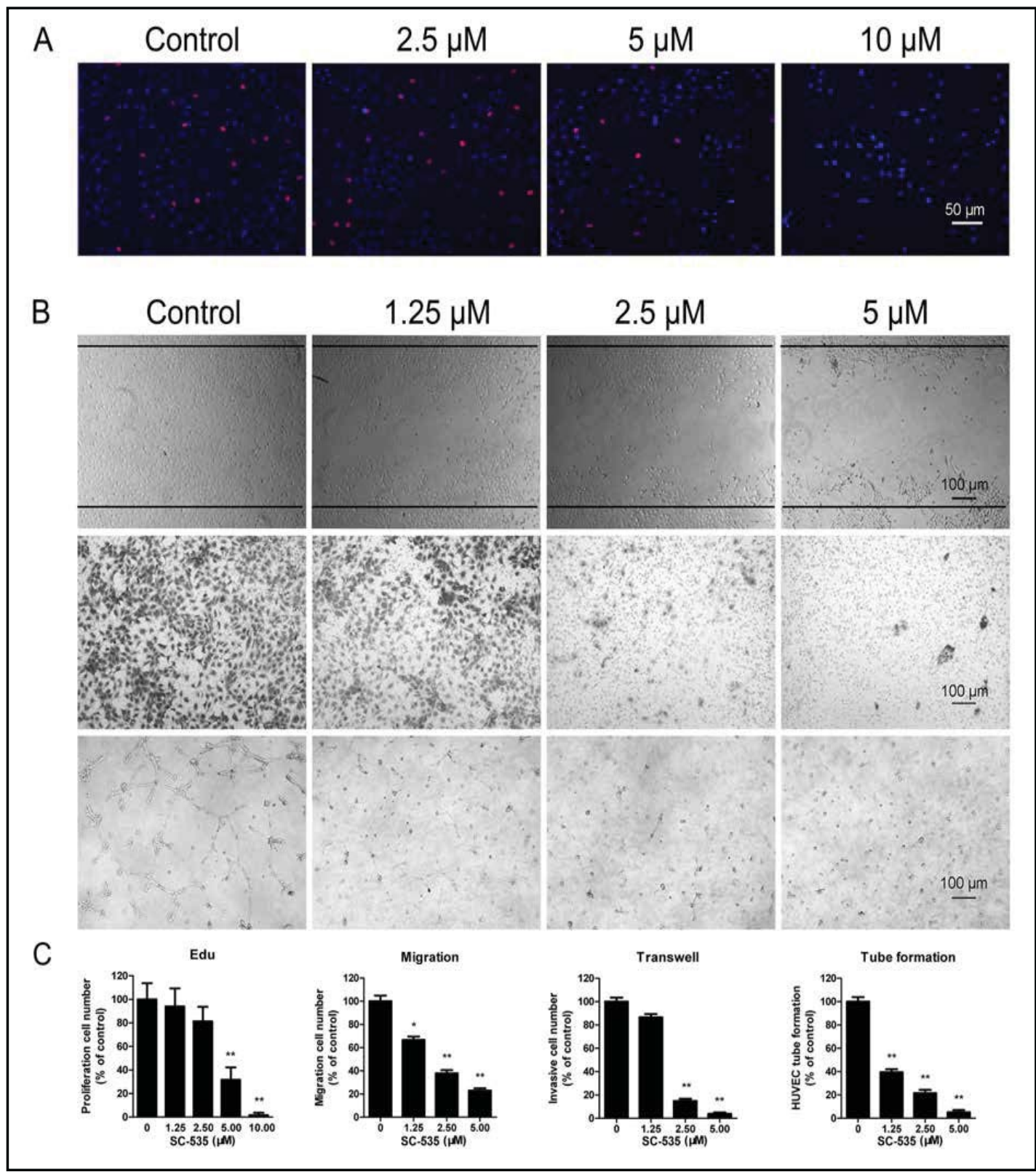

Fig. 2. Inhibitory effects of SC-535 against HUVEC proliferation, migration, invasion, and tube formation. (A) SC-535 inhibited HUVEC proliferation. The proliferating cells were detected using an EdU kit after a 24 $\mathrm{h}$ treatment with the indicated concentrations of SC-535. The blue nuclei represent the nucleus and the red represent the cells in S phase. (B) SC-535 inhibited the migration of HUVEC in wound healing assay. Cells were seeded in 24 Well Cell Culture Plate. After $24 \mathrm{~h}$, the confluent cell monolayers were wounded manually and treated with $0.1 \%$ DMSO or indicated concentrations of SC-535. After $24 \mathrm{~h}$, images were captured using an inverted microscope, and the black lines in each image represent the initial wound (up panels). SC-535 inhibited the invasion of HUVEC in Transwell assay. $2 \times 10^{4}$ HUVEC were planted in which were pre-treated with Matrigel on the upper chamber membrane and treated with vehicle or various concentrations of SC-535, and the bottom chamber was filled with EBM2 medium containing $50 \mathrm{ng} / \mathrm{ml}$ VEGF. Cells with an irregular shape in images are HUVEC that invaded into the lower chamber (middle panels). The inhibition of vascular tube formation by SC-535 was dose dependent. Various concentrations of SC-535 inhibited tube formation by HUVEC on Matrigel (down panels). (C) The statistical data of inhibitory effects of SC-535 against HUVEC proliferation, migration, invasion, and tube formation. Column, mean; bars, SEM ( $\mathrm{n}=9$; *, $\mathrm{P}<0.05 ;{ }^{* *}, \mathrm{P}<0.01$ vs. the control, PRISM). 
Fig. 3. Western blot analysis of HUVEC following SC-535 treatment. HUVEC were treated with SC535 and sorafenib at various concentrations. SC535 inhibits the activation of VEGFR2-mediated SRC, FAK, AKT and ERK proteins in HUVEC.

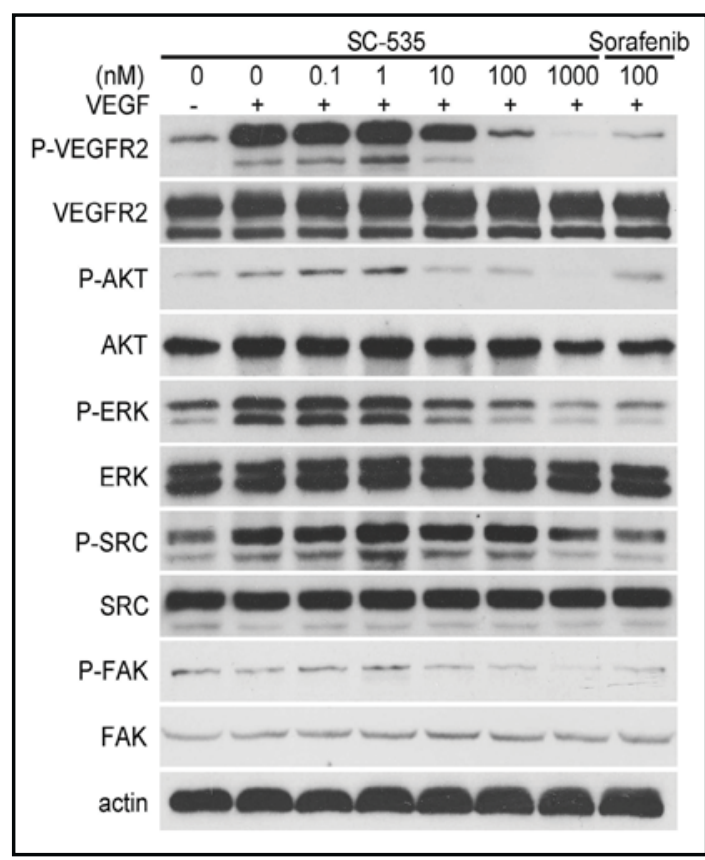

Fig. 4. SC-535 inhibits angiogenesis in vivo. (A) $33 \mathrm{hpf}$ zebrafish embryos treated with blank control or 1.25 $\mu \mathrm{M}, 2.5 \mu \mathrm{M}$, or $5 \mu \mathrm{M}$ SC535. Intersegmental vessel (ISV) budding and outgrowth were almost completely inhibited by treatment with $5 \mu \mathrm{M}$ SC-535. Column, mean; bars, SEM $(\mathrm{n}=10 ; * *$, $\mathrm{P}<0.01$ vs. the control, PRISM). (B) Vascularization of alginate implants. SC-535 was administered orally once daily for $14 \mathrm{~d}$ after injection of

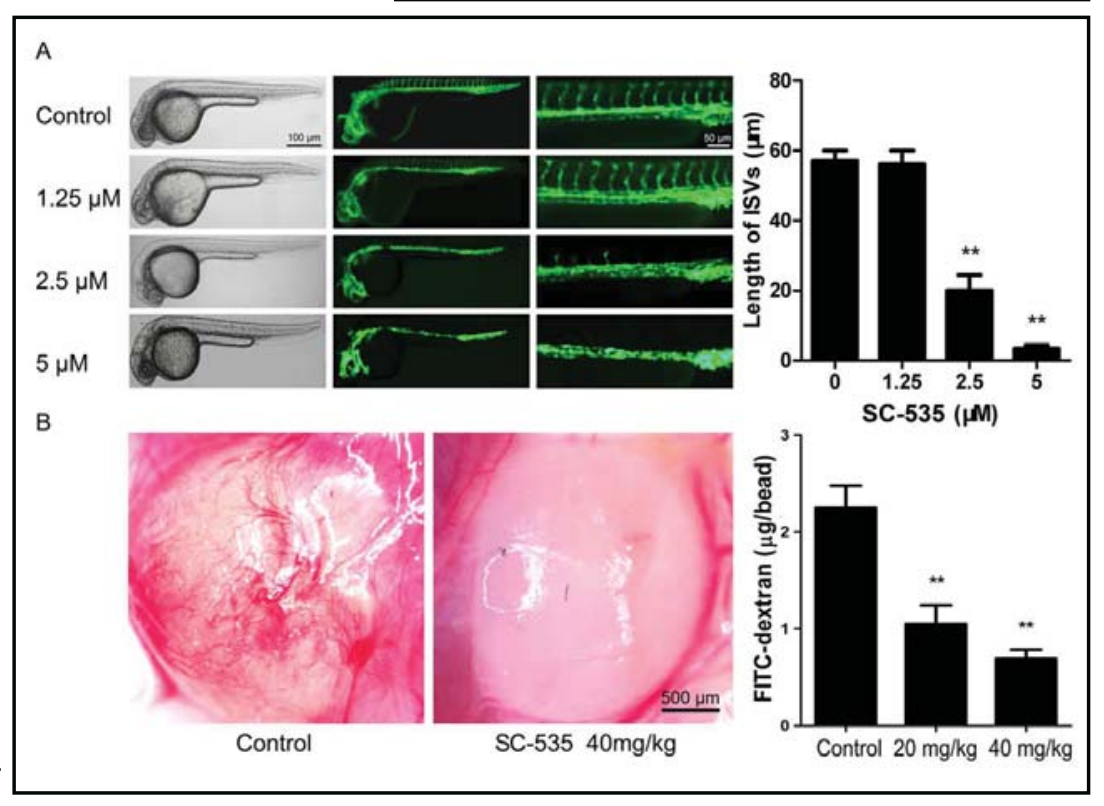
the alginate beads. On day 14, beads were surgically removed and FITC-dextran was quantified as described in Materials and Methods. Column, mean; bars, SD ( $\mathrm{n}=6$; **, $\mathrm{P}<0.01$ vs. the control, PRISM).

ding AKT, ERK, FAK and SRC were also significantly suppressed (Fig. 3). All of these suggested that SC-535 exerted its antiangiogenic function via directly targeting VEGFR2.

\section{In vivo antiangiogenic effects of SC-535}

Transgenic zebrafish assays were carried out to examine the antiangiogenic ability of SC-535 in vivo. Fig. $4 \mathrm{~A}$ shows $33 \mathrm{hpf}$ zebrafish embryos treated with $1.25 \mu \mathrm{M}, 2.5 \mu \mathrm{M}$, and 5 $\mu \mathrm{M}$ SC-535, as well as a blank control. Treatment of live fish embryos with SC-535 completely blocked the formation of intersegmental vessels (ISVs) at a concentration of $5 \mu \mathrm{M}$ while preserving fluorescence in the doral aorta and major cranial vessels. At $1.25 \mu \mathrm{M}$ or $2.5 \mu \mathrm{M}$ SC-535, the formation of intersegmental vessels was considerably inhibited compared with the vehicle control group, indicating a dose-dependent inhibition pattern. 


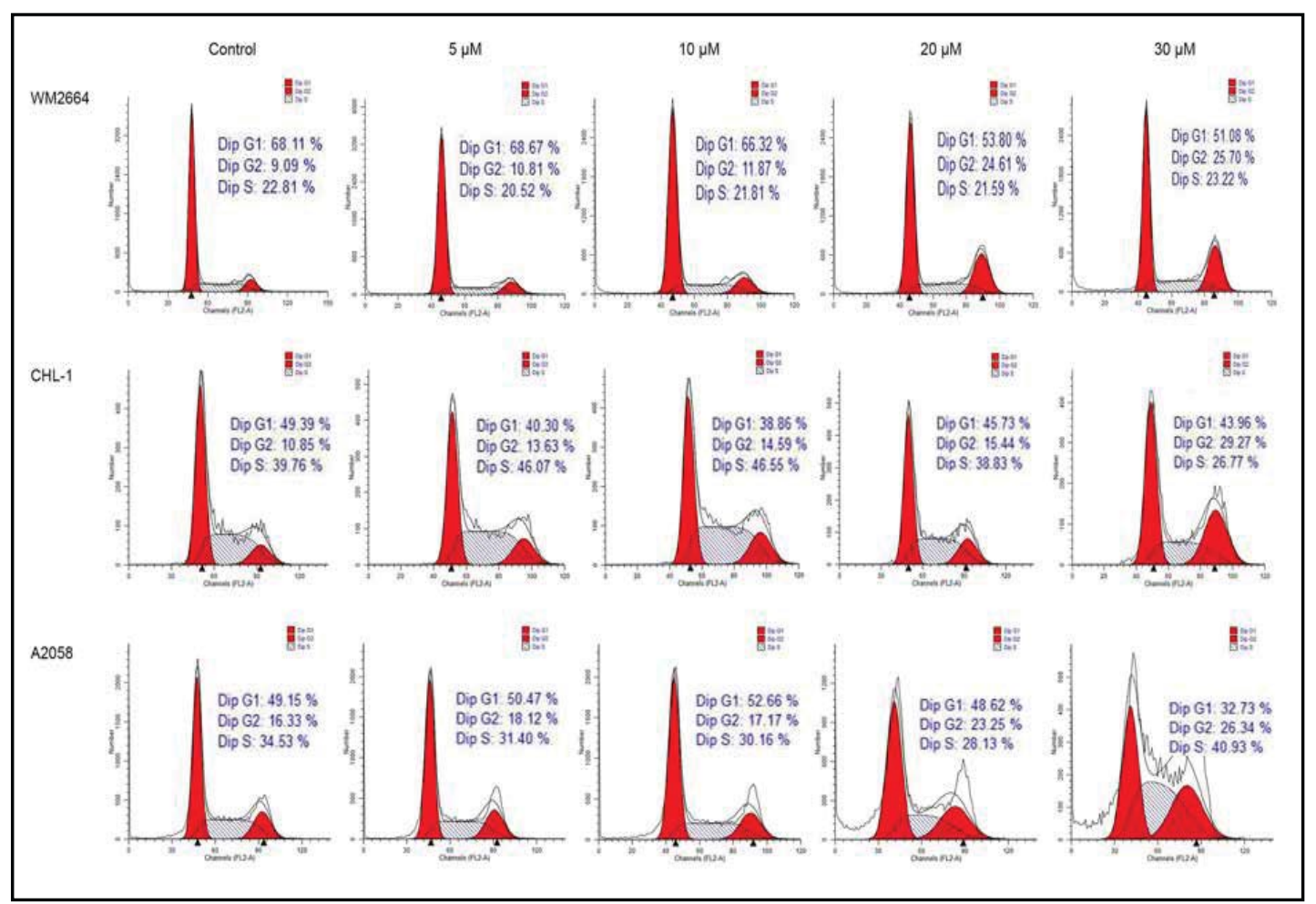

Fig. 5. FCM analysis of cell cycle arrest in melanoma cells before and after SC-535 treatment. Each cell line was treated with various concentrations of SC-535 for $24 \mathrm{~h}$. PI-stained cells were detected by flow cytometry.

Fig. 6. Western blot analysis of WM2664 cells following SC-535 treatment. Cells were lysed and the various proteins involving cell cycle and MAPK signal pathway were analyzed by Western blot analysis.

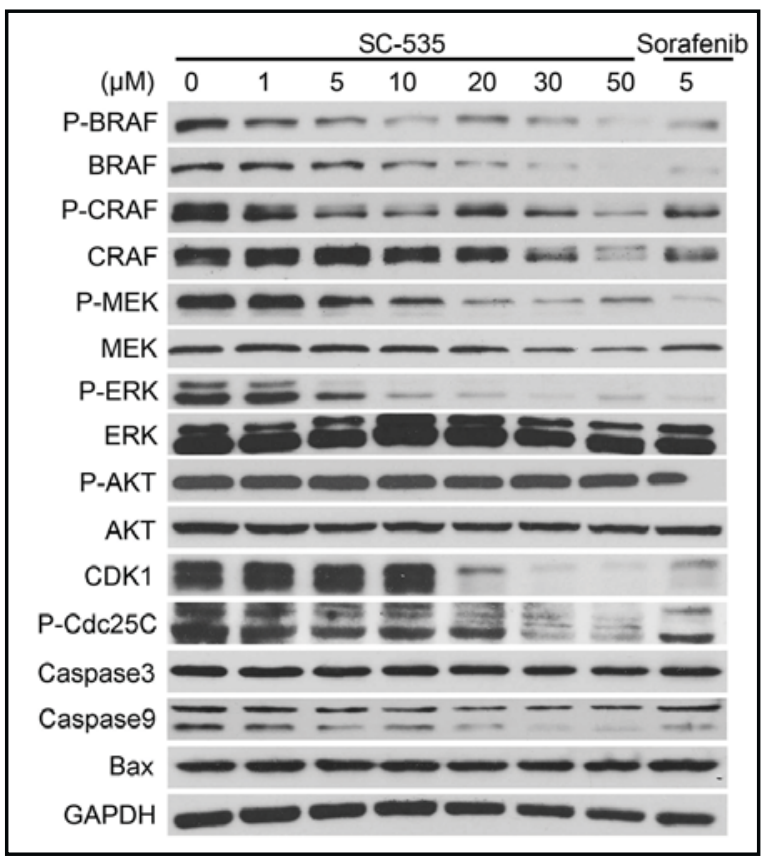

Finally, to better mimic the process of angiogenesis induced by tumor cells in vivo and determine the inhibitory effect of SC-535 on it, we performed an alginate-encapsulate tumor cell assay. In SC-535-treated mice, new blood vessels in alginate beads were apparently reduced and FITC-dextran uptake was significantly decreased when compared with control group (Fig. 4B). 
Fig. 7. SC-535 inhibits tumor growth in two melanoma xenograft models. (A) Mice implanted with WM2664 xenografts were treated when the tumors grew to about $200 \mathrm{~mm}^{3}$. Animals (6 per group) were treated with vehicle or SC-535 at doses of 12.5 $\mathrm{mg} / \mathrm{kg}, 25 \mathrm{mg} /$ $\mathrm{kg}$, and $50 \mathrm{mg} /$ $\mathrm{kg}$ with sorafen$\mathrm{ib}$ at a dose of $50 \mathrm{mg} / \mathrm{kg}$ once daily for $24 \mathrm{~d}$. Efficacy data are plotted as mean tumor volume $\left(\mathrm{mm}^{3}\right) \pm$ SEM; $(n=6)$. (B) Body weight of animals in WM2664 xenograft models. Mean body weight (g) \pm SEM; $(n=6) . \quad(C)$ Mice implanted with C32 xenografts were treated when the tumors grew to about 150-200 $\mathrm{mm}^{3}$. Animals (6 per group) were treated with ve-
A

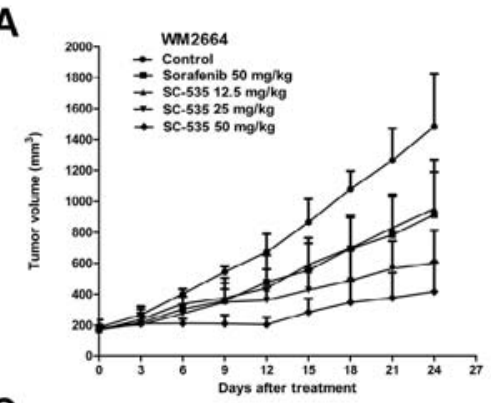

C

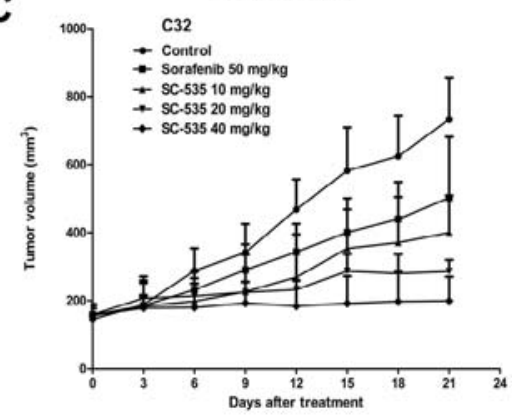

E

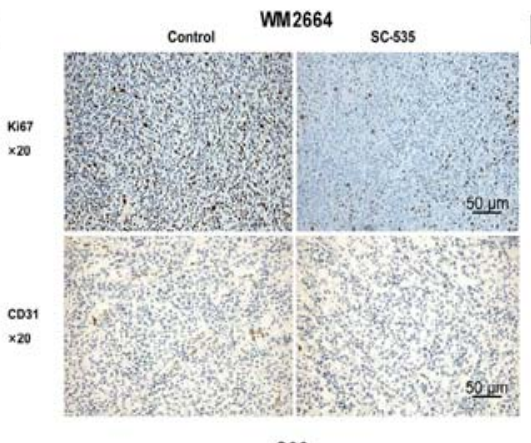

G

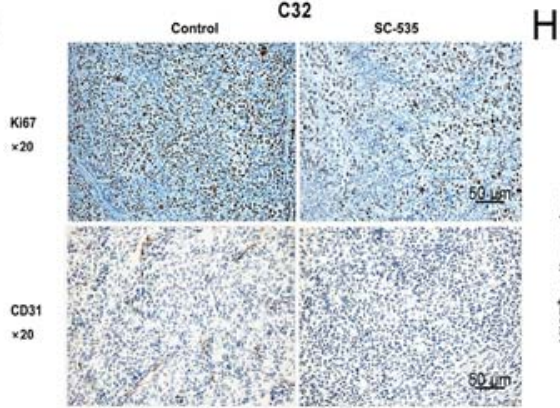

B

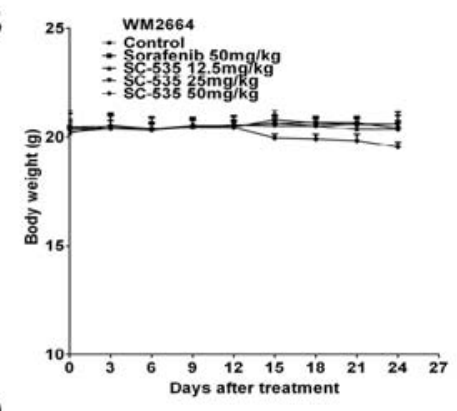

D

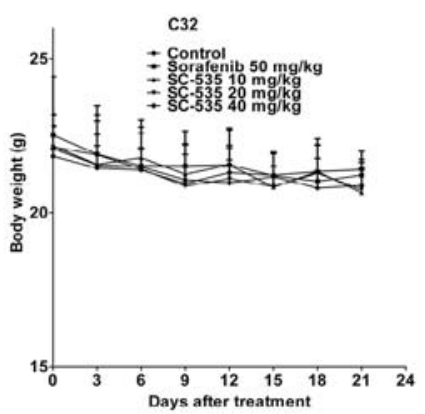

F

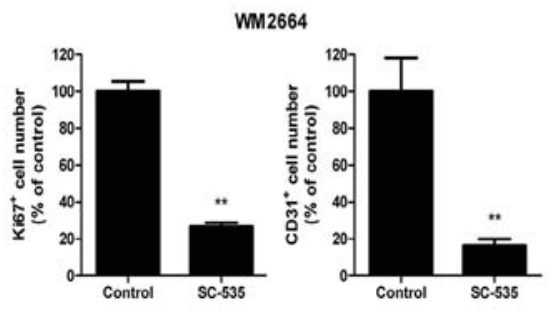

$\mathrm{H}$
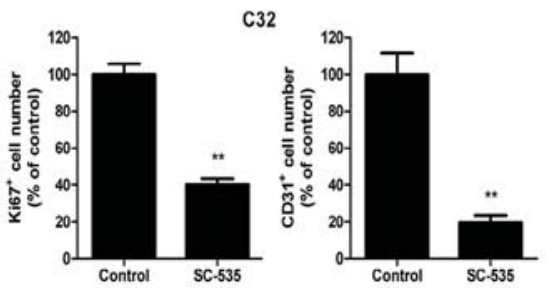

hicle or SC-535 at doses of $10 \mathrm{mg} / \mathrm{kg}, 20 \mathrm{mg} / \mathrm{kg}$, and $40 \mathrm{mg} / \mathrm{kg}$, or sorafenib at a dose of $50 \mathrm{mg} / \mathrm{kg}$ once daily for $21 \mathrm{~d}$. Efficacy data are plotted as mean tumor volume $\left(\mathrm{mm}^{3}\right) \pm \mathrm{SEM}$; $(\mathrm{n}=6)$. (D) Body weight of animals in C32 xenograft models. Mean body weight (g) \pm SEM; (n=6). (E) After $10 \mathrm{~d}$ of 50mg/kg SC-535 treatment, the WM2664 tumors (3 per group) were collected separately. Histological sections of control and SC-535-treated WM2664 tumors were stained with Ki67 and CD31. Ki67 and CD31 stained cells were significantly reduced after SC-535 treatment. (F) The statistical data of Ki67 and CD31 positive cell number in the tumors of WM2664 xenograft models. Column, mean; bars, SEM (n=9; **, P < 0.01 vs. the control, PRISM). (G) Similar to WM2664, after $10 \mathrm{~d}$ of $40 \mathrm{mg} / \mathrm{kg}$ SC-535 treatment, the C32 tumors (3 per group) were collected separately. Histological sections of control and SC-535-treated C32 tumors were stained with Ki67 and CD31. Ki67 and CD31 stained C32 cells reduced after SC-535 treatment. (H) The statistical data of Ki67 and CD31 positive cell number in the tumors of C32 xenograft models. Column, mean; bars, SEM ( $\mathrm{n}=9$; **, $\mathrm{P}<0.01$ vs. the control, PRISM). 


\section{Cellular Physiology and Biochemistry}

Cell Physiol Biochem 2013;32:138-153

DOI: $10.1159 / 000350123$

Published online: July 12, 2013

C) 2013 S. Karger AG, Basel

www.karger.com/cpb

\section{SC-535 induced cell cycle arrest but not apoptosis in melanoma cell lines}

To determine whether the killing effects of SC-535 on melanoma cell lines were due to apoptosis or cell cycle arrest, the melanoma WM2664, A2058 and CHL-1 cells were exposed to SC-535 at concentrations ranging from $0 \mu \mathrm{M}$ to $30 \mu \mathrm{M}$ for $24 \mathrm{~h}$, and the samples with PI staining of nuclei were analyzed by flow cytometry. For WM2664, treatment with SC-535 led a considerable increase of the number of cells in G2 phase (from 9.09\% to 25.70\%) with the increase of SC-535 concentration from $0 \mu \mathrm{M}$ to $30 \mu \mathrm{M}$, and no obvious apoptotic cells were found, which indicated that SC-535 treatment did not induce apoptosis but G2/M arrest in WM2664 (Fig. 5, up panels). The similar effects of SC-535 on A2058 and CHL-1 were observed (Fig. 5, down and middle panels, respectively).

To further understand the mechanisms of action, we measured the expression levels or activation status of a number of key proteins involved in the G2/M phase transition or apoptosis before and after SC-535 treated by western blot analysis in WM2664 cell line. Notably, SC-535 down-regulated CDK1 and P-Cdc25C in a dose dependent pattern (Fig. 6); CDK1 and Cdc25C are considered as direct regulators of G2/M phase transition. SC-535 also suppressed the activation of BRAF, CRAF, MEK, and ERK, which are important modulators of cell proliferation. In contrast, until a concentration of $30 \mu \mathrm{M}$, SC-535 did not show significant influence on Bax, Caspase3, Caspase9, and AKT, which are associated with cell apoptosis.

\section{In vivo anti-melanoma activity of SC-535}

The in vivo anti-melanoma activity of SC-535 was assessed using the WM2664 and C32 xenograft mouse models. For the WM2664 model, when the tumor grew to a volume of approximate $200 \mathrm{~mm}^{3}$, the mice were grouped and treated orally once daily with 12.5 $\mathrm{mg} / \mathrm{kg} / \mathrm{d}, 25 \mathrm{mg} / \mathrm{kg} / \mathrm{d}$, or $50 \mathrm{mg} / \mathrm{kg} / \mathrm{d}$ SC-535 for about 3 weeks. The tumor volumes were measured every $3 \mathrm{~d}$. It was found that $12.5 \mathrm{mg} / \mathrm{kg} \mathrm{SC}-535$ could suppress tumor growth with a tumor inhibition rate of about $40 \%$ compared with vehicle group (Fig. 7A); the efficacy is comparable to that of $50 \mathrm{mg} / \mathrm{kg}$ sorafenib. SC-535 treatment at $50 \mathrm{mg} / \mathrm{kg} / \mathrm{d}$ showed considerable tumor suppression ability with a tumor inhibition rate of about $90 \%$ compared with the vehicle group (Fig. 7A). Moreover, during the whole experiment, no significant weight loss or any other obvious signs of toxicity were observed for all of the SC-535-treated mice (Fig. 7B).

To understand the mechanisms of action responsible for the anti-tumor effects, SC-535 was evaluated for its effects on the tumor mitotic index (Ki67) and antiangiogenesis using histological and immunohistochemical techniques. Similar to the tumor xenograft models, a dose of $50 \mathrm{mg} / \mathrm{kg} / \mathrm{d}$ of SC-535 was administered through oral gavage for the WM2664 model. After treatment for $10 \mathrm{~d}$, tumors were collected and analyzed. Tumor tissues from the vehicle group stained strongly with Ki67, indicating a large number of highly proliferative cells (Fig. 7E and Fig. 7F). Conversely, the tumor tissues from the SC-535-treated groups showed a considerable fewer Ki67-positive cells. Immunohistochemical staining of the tumor tissue from SC-535-treated mice with anti-CD31 showed significantly decreased microvessel density compared with vehicle groups (Fig. 7E and Fig. 7F).

In the C32 xenograft model, a series of doses including $10 \mathrm{mg} / \mathrm{kg}, 20 \mathrm{mg} / \mathrm{kg}$ and 40 $\mathrm{mg} / \mathrm{kg}$ of SC-535 were administered orally once daily when the tumors grew to 150 200 $\mathrm{mm}^{3}$. The tumor inhibition rates of SC-535 at doses of $10 \mathrm{mg} / \mathrm{kg} / \mathrm{d}, 20 \mathrm{mg} / \mathrm{kg} / \mathrm{d}$, and 40 $\mathrm{mg} / \mathrm{kg} / \mathrm{d}$ are $58 \%, 78 \%$, and $92 \%$, respectively, whereas sorafenib displayed a weak tumor suppressive effect at a dose of $50 \mathrm{mg} / \mathrm{kg} / \mathrm{d}$ (Fig. 7C). Besides, during the whole experiment, significant weight loss or any other obvious signs of toxicity were not observed for all of the SC-535-treated mice (Fig. 7D).

Histological and immunohistochemical analyses were performed to examine the anti-tumor mechanisms of action of SC-535 in the C32 model. A dose of $40 \mathrm{mg} / \mathrm{kg} / \mathrm{d}$ of SC-535 was administered orally once daily. Similar to the process for the WM2664 model, after $10 \mathrm{~d}$ of treatment, tumors were collected and analyzed. The percentage of Ki67-expressing cells in viable tumor tissue was considerably lower following SC-535 treatment (Fig. 7G and Fig. $7 \mathrm{H})$, indicating a considerable reduction in the number of proliferating cells in the tumors. 
Table 4. Pharmacokinetic characteristics of SC-535 $(10 \mathrm{mg} / \mathrm{kg})$. Note: i.v = intravenous injection, $\mathrm{p} . \mathrm{o}=$ oral delivery, $\mathrm{C}_{\max }=$ maximum plasma concentration, $\mathrm{AUC}=$ area under the curve, $\mathrm{T}_{1 / 2}=$ half life, $\mathrm{CL}=$ plasma clearance, $V_{\text {ss }}=$ volume of distribution, $\mathrm{F}=$ oral bioavailability

\begin{tabular}{cccc}
\hline Parameters & Unit & p.o & i.v \\
\hline AUC $(0-\mathrm{t})$ & ug*h $/ \mathrm{ml}$ & 318.82 & 478.22 \\
$\mathrm{~T}_{1 / 2}$ & $\mathrm{~h}$ & 12.61 & 8.65 \\
$\mathrm{~T}_{\max }$ & $\mathrm{h}$ & 7.20 & 0.033 \\
$\mathrm{CL}$ & $\mathrm{l} / \mathrm{h} / \mathrm{kg}$ & 0.030 & 0.022 \\
$\mathrm{~V}_{\text {ss }}$ & $\mathrm{l} / \mathrm{kg}$ & 0.51 & 0.27 \\
$\mathrm{C}_{\max }$ & $\mathrm{ug} / \mathrm{ml}$ & 15.12 & 58.65 \\
$\mathrm{~F}$ & & $66.67 \%$ & \\
\hline
\end{tabular}

Fig. 8. Plasma concentrations curve of SC-535 in male rats after a single dose of $10 \mathrm{mg} / \mathrm{kg}$. Male rats received a dose of $10 \mathrm{mg} / \mathrm{kg} \mathrm{SC}-535$ by oral gavage. At the indicated times, blood was collected and the plasma concentration of SC-535 was determined by LC/MS. Points, mean; bars, $\operatorname{SD}(\mathrm{n}=5)$.

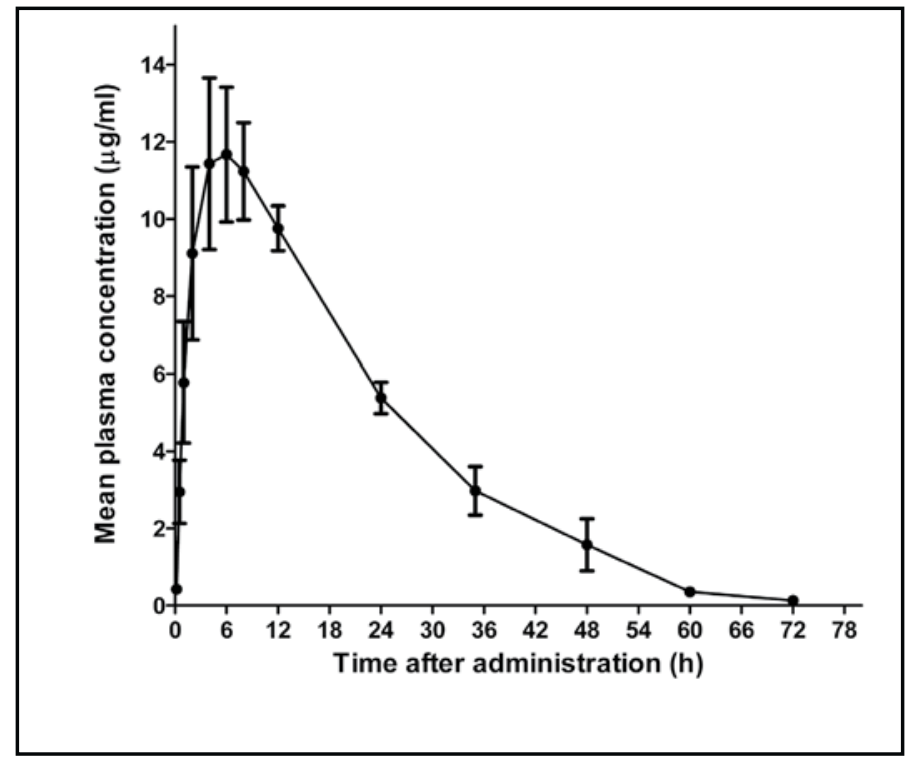

Furthermore, immunohistochemical analyses showed that SC-535 decreased the microvessel density compared with vehicle-treated tumors.

\section{Pharmacokinetic characteristics of SC-535}

Pharmacokinetic parameters of SC-535 following intravenous and per os administration to male rats were measured, the results of which are summarized in Table 4 . The plasma concentration versus time profile of SC-535 is shown in Fig. 8. After intravenous injection at the dose of $10 \mathrm{mg} / \mathrm{kg}$, SC-535 displayed a clearance of $0.022 \mathrm{l} / \mathrm{h} / \mathrm{kg}$, with a $\mathrm{T}_{1 / 2}$ of $8.65 \mathrm{~h}$. Following oral administration at a single dose of $10 \mathrm{mg} / \mathrm{kg}$, the absorption of SC-535 was relatively quick, which reached the maximum concentration in the plasma $\left(\mathrm{C}_{\max }, 15.12 \mathrm{mg} / \mathrm{ml}\right)$ at 2 to $8 \mathrm{~h}$. SC-535 displayed a clearance of $0.03 \mathrm{l} / \mathrm{h} / \mathrm{kg}$, with a $\mathrm{T}_{1 / 2}$ of $12.61 \mathrm{~h}$. The absolute oral bioavailability of SC-535 was $66.67 \%$ after an oral dose of $10 \mathrm{mg} / \mathrm{kg}$.

\section{Discussion}

Although advanced melanoma remains an untreatable disease, considerable progress has recently been achieved in identifying the contributing oncogenes and targeted small-molecule inhibitors $[3,9]$. Targeted therapies directed against single oncogene or single signaling pathway have produced major clinical responses in a fairly predictable manner [31]. However, these responses are often incomplete or not durable [32]. Multi-targeted therapies that simultaneously target several key oncogenes or signaling pathways are needed [33]. SC535 assessed in this investigation is a novel small molecule multi-kinase inhibitor. Kinases that SC-535 can efficiently inhibit mainly include VEGFR, BRAF ${ }^{\mathrm{V} 600 \mathrm{E}}, \mathrm{BRAF}^{\mathrm{WT}}$, CRAF, KIT, and 


\section{Cellular Physiology and Biochemistry}

Cell Physiol Biochem 2013;32:138-153

\begin{tabular}{l|l}
\hline DOI: $10.1159 / 000350123$ & (C) 2013 S. Karger AG, Basel
\end{tabular}

Published onlıne: July 12, 2013

www.karger.com/cpb

Chen et al.: SC-535, a Multikinase Inhibitor, Anti-Melanoma

FGFR. Among them, VEGFR and FGFR are associated with angiogenesis [34-36]. BRAFV600E, $\mathrm{BRAF}^{\mathrm{WT}}$, and CRAF are key components of the MAPK signaling pathway, which is involved in various cellular functions, including cell proliferation, differentiation, and migration $[4,7$, 37].

As indicated above, melanomas are highly vascular tumors. Although antiangiogenic agent sorafenib failed as monotherapy in metastasized melanoma, a recent clinical study indicated that patients with stage IV uveal melanoma might benefit from treatment with sorafenib [38-40]. Compared with sorafenib, SC-535 showed a higher potency in inhibition of several key kinases associated with angiogenesis, for example, the $\mathrm{IC}_{50}$ value of SC-535 against VEGFR2 is $12 \mathrm{nM}$, and that of sorafenib is $90 \mathrm{nM}$. In vivo, it also displayed a better anti-tumor activity in WM2664 and C32 xenograft mouse models compared with sorafenib.

Flow cytometric analysis showed that SC-535 induced G2/M phase arrest, instead of apoptosis (that is one of the action mechanisms of sorafenib) [41], in melanoma cells. This has been confirmed by the subsequent Western blot experiment. On the one hand, SC-535 had no effect on apoptosis-related proteins such as Caspase3 and 9, Bax, and AKT. On the other hand, the cell cycle protein Cdk1, which must be activated for cells to enter mitosis, was inhibited by SC-535 in a dose dependent pattern. The inhibition of Cdk1 might be, at least partly, due to the blockade of MAPK signaling and the down-regulation of Cdc25C by SC-535 [42, 43].

Recently, several studies have reported that selective BRAF inhibitors might lead to drug resistance in most clinical cases because BRAF inhibition can re-activate MAPK signaling in melanoma cells via the ERK-dependent feedback [32, 44, 45]. They also demonstrated that elevated CRAF protein levels were responsible for the primary insensitivity to RAF inhibition [46, 47]. SC-535 inhibited both BRAF and CRAF, which might help to overcome the resistance to BRAF inhibition. This hypothesis is supported by the fact that we did not observe increased ERK activation in WM2664 cells after $24 \mathrm{~h}$ treatment of SC-535 in various concentrations.

In conclusion, we have assessed the preclinical anti-melanoma activities for the novel multi-kinase inhibitor SC-535. The results showed that this compound had a considerable potency in anti-melanoma both in vitro and in vivo. Mechanism studies have indicated that it has a strong antiangiogenesis activity. SC-535 can arrest the tumor cell cycle in G2/M phase, other than induce apoptosis. SC-535 has the convenience of oral administration, favorable pharmacokinetic properties and low toxicity. Collectively, this study establishes a favorable preclinical profile of SC-535, which may support SC-535 as a good candidate for clinical studies as a single agent or combination with other targeted agents or chemotherapeutic drugs in patients with melanoma.

\section{Abbreviations}

VEGFR (vascular endothelial growth factor receptor); DMSO (Dimethyl Sulfoxide); PI (Propidium Iodide); EdU (5-Ethynyl-2'-Deoxyuridine); MAPK (Mitogen-Activated Protein Kinase); CDK (Cyclin-Dependent Kinase); OS (overall survival); DMEM (Dulbecco's modified Eagle's medium); FBS (fetal bovine serum); HUVEC (Human umbilical vein endothelial cells); MTT (3-(4,5)-Dimethylthiahiazo(-z-y1)-3,5-Di-phenytetrazoliumromide); flow cytometry (FCM); hours post-fertilization (hpf); hour/hours (h); day/days(d); American Type Culture Collection (ATCC); tumor volume (TV); liquid chromatography/mass spectrometry (LC/MS); intersegmental vessels (ISVs).

\section{Conflict of Interest}

None declared. 


\section{Acknowledgements}

This work was supported by the National Natural Science Foundation of China (81172987), the 973 Program (2013CB967204), and the 863 Hi-Tech Program (2012AA020301, 2012AA0203).

\section{References}

1 American Cancer Society. Cancer Facts \& Figures 2012. Atlanta: American Cancer Society; 2012.

2 Miller AJ, Mihm MC: Mechanisms of disease melanoma. N Engl J Med 2006;355:51-65.

-3 Flaherty KT, Hodi FS, Fisher DE: From genes to drugs: Targeted strategies for melanoma. Nat rev Cancer 2012;12:349-361.

4 Chang L, Karin M: Mammalian map kinase signalling cascades. Nature 2001;410:37-40.

5 Dhillon AS, Hagan S, Rath 0, Kolch W: Map kinase signalling pathways in cancer. Oncogene 2007;26:32793290.

-6 Davies H, Davies H, Bignell GR, Cox C, Stephens P, Edkins S, Clegg S, Teague J, Woffendin H, Garnett MJ, Bottomley W, Davis N, Stratton MR, Futreal PA: Mutations of the braf gene in human cancer. Nature 2002;417:949-954.

7 Hoeflich KP, Gray DC, Eby MT, Tien JY, Wong L, Bower J, Gogineni A, Zha J, Cole MJ, Stern HM, Murray LJ, Davis DP, Seshagiri S: Oncogenic braf is required for tumor growth and maintenance in melanoma models. Cancer Res 2006;66:999-1006.

-8 Kolch W, Kotwaliwale A, Vass K, Janosch P: The role of raf kinases in malignant transformation. Expert Rev Mol Med 2002;4:1-18.

9 Bastian B, Lo R, Ribas A: Society for melanoma research 2012 congress. Pigment Cell Melanoma Res 2012;25:836-903.

10 Claffey KP, Brown LF, del Aguila LF, Tognazzi K, Yeo KT, Manseau EJ, Dvorak HF: Expression of vascular permeability factor/vascular endothelial growth factor by melanoma cells increases tumor growth, angiogenesis, and experimental metastasis. Cancer Res 1996;56:172-181.

11 Pralhad T, Madhusudan S, Rajendrakumar K: Concept, mechanisms and therapeutics of angiogenesis in cancer and other diseases. J Pharm Pharmacol 2003;55:1045-1053.

-12 Bergers G, Benjamin LE: Tumorigenesis and the angiogenic switch. Nat rev Cancer 2003;3:401-410.

13 Hanahan D, Folkman J: Patterns and emerging mechanisms of the angiogenic switch during tumorigenesis. Cell 1996;86:353-364.

14 Cheng AL, Kang YK, Chen Z, Tsao CJ, Qin S, Kim JS, Luo R, Feng J, Ye S, Yang TS, Xu J, Sun Y, Liang H, Liu J, Wang J, Tak WY, Pan H, Burock K, Zou J, Voliotis D, Guan Z: Efficacy and safety of sorafenib in patients in the asia-pacific region with advanced hepatocellular carcinoma: A phase iii randomised, double-blind, placebo-controlled trial. Lancet Oncol 2009;10:25-34.

-15 Mangana J, Levesque MP, Karpova MB, Dummer R: Sorafenib in melanoma. Expert Opin Investig Drugs 2012;21:557-568.

16 Eisen T, Ahmad T, Flaherty KT, Gore M, Kaye S, Marais R, Gibbens I, Hackett S, James M, Schuchter LM, Nathanson KL, Xia C, Simantov R, Schwartz B, Poulin-Costello M, O`Dwyer PJ, Ratain MJ: Sorafenib in advanced melanoma: A phase ii randomised discontinuation trial analysis. Br J Cancer 2006;95:581-586.

17 Wilhelm S, Carter C, Lynch M, Lowinger T, Dumas J, Smith RA, Schwartz B, Simantov R, Kelley S: Discovery and development of sorafenib: A multikinase inhibitor for treating cancer. Nat Rev Drug Discov 2006;5:835-844.

18 Fruehauf J, Lutzky J, McDermott D, Brown CK, Meric JB, Rosbrook B, Shalinsky DR, Liau KF, Niethammer AG, Kim S, Rixe O: Multicenter, phase ii study of axitinib, a selective second-generation inhibitor of vascular endothelial growth factor receptors 1, 2, and 3, in patients with metastatic melanoma. Clin Cancer Res 2011;17:7462-7469. 


\section{Cellular Physiology and Biochemistry}

Cell Physiol Biochem 2013;32:138-153

\begin{tabular}{l|l}
\hline DOI: $10.1159 / 000350123$ & (C) 2013 S. Karger AG, Basel
\end{tabular}

www.karger.com/cpb

Chen et al.: SC-535, a Multikinase Inhibitor, Anti-Melanoma

19 Matsui J, Funahashi Y, Uenaka T, Watanabe T, Tsuruoka A, Asada M: Multi-kinase inhibitor e7080 suppresses lymph node and lung metastases of human mammary breast tumor mda-mb-231 via inhibition of vascular endothelial growth factor-receptor (vegf-r) 2 and vegf-r3 kinase. Clin Cancer Res 2008;14:54595465 .

20 Schicher N, Paulitschke V, Swoboda A, Kunstfeld R, Loewe R, Pilarski P, Pehamberger H, Hoeller C: Erlotinib and bevacizumab have synergistic activity against melanoma. Clin Cancer Res 2009;15:3495-3502.

21 Garcia-Gomez A, Ocio EM, Pandiella A, San Miguel JF, Garayoa M: Raf265, a dual braf and vegfr2 inhibitor, prevents osteoclast formation and resorption. Therapeutic implications. Invest New Drugs 2013;31:200205.

22 Yang LL, Li GB, Ma S, Zou C, Zhou S, Sun QZ, Cheng C, Chen X, Wang LJ, Feng S, Li LL, Yang SY: Structure activity relationship studies of pyrazolo[3,4-d ]pyrimidine derivatives leading to the discovery of a novel multikinase inhibitor that potently inhibits flt 3 and vegfr 2 and valuation of its activity against acute myeloid leukemia in vitro and in vivo. J Med Chem 2013;56:1641-1655.

23 Lewis LJ, Hoak JC, Maca RD, Fry GL: Replication of human endothelial cells in culture. Science 1973;181:453-454.

24 Heo DS, Park JG, Hata K, Day RM, Herberman RB, Whiteside TL: Evaluation of tetrazolium-based semiautomatic colorimetric assay for measurement of human antitumor cytotoxicity. Cancer Res 1990;50:36813690.

25 Cappella P, Gasparri F, Pulici M, Moll J: A novel method based on click chemistry, which overcomes limitations of cell cycle analysis by classical determination of brdu incorporation, allowing multiplex antibody staining. Cytometry A 2008;73:626-636.

26 Dai XY, Zeng XX, Peng F, Han YY, Lin HJ, Xu YZ, Zhou T, Xie G, Deng Y, Mao YQ, Yu LT, Yang L, Zhao YL: A novel anticancer agent, sklb70359, inhibits human hepatic carcinoma cells proliferation via g0/g1 cell cycle arrest and apoptosis induction. Cell Physiol Biochem 2012;29:281-290.

-27 Pan YL, Xu Y, Feng S, Luo SD, Zheng RL, Yang J, Wang LJ, Zhong L, Yang HY, Wang BL, Yu Y, Liu JJ, Cao ZX, Wang XY, Ji P, Wang ZR, Chen X, Zhang S, Wei YQ Yang SY: Sklb1206, a novel orally available multikinase inhibitor targeting egfr activating and $\mathrm{t} 790 \mathrm{~m}$ mutants, erbb2, erbb4, and vegfr2, displays potent antitumor activity both in vitro and in vivo. Mol Cancer Ther 2012;11:952-962.

-28 Cao ZX, Zheng RL, Lin HJ, Luo SD, Zhou Y, Xu YZ, Zeng XX, Wang Z, Zhou LN, Mao YQ Yang L, Wei YQ Yu LT, Yang SY, Zhao YL: Sklb610: A novel potential inhibitor of vascular endothelial growth factor receptor tyrosine kinases inhibits angiogenesis and tumor growth in vivo. Cell Physiol Biochem 2011;27:565-574.

-29 Hoffmann J, Schirner M, Menrad A, Schneider MR: A highly sensitive model for quantification of in vivo tumor angiogenesis induced by alginate-encapsulated tumor cells. Cancer Res 1997;57:3847-3851.

- 30 Zhang S, Cao ZX, Tian HW, Shen GB, Ma YP, Xie HZ, Liu YL, Zhao CJ, Deng SY, Yang Y, Zheng RL, Li WW, Zhang N, Liu SY, Wang W, Dai L, Shi S, Cheng L, Pan YL, Feng S, Zhao X, Deng HX, Yang SY, Wei YQ: Sklb1002, a novel potent inhibitor of vegf receptor 2 signaling, inhibits angiogenesis and tumor growth in vivo. Clin Cancer Res 2011;17:4439-4450.

-31 Yang H, Higgins B, Kolinsky K, Packman K, Go Z, Iyer R, Kolis S, Zhao S, Lee R, Grippo JF, Schostack K, Simcox ME, Heimbrook D, Bollag G, Su F: Rg7204 (plx4032), a selective brafv600e inhibitor, displays potent antitumor activity in preclinical melanoma models. Cancer Res 2010;70:5518-5527.

-32 Villanueva J, Vultur A, Herlyn M: Resistance to braf inhibitors: Unraveling mechanisms and future treatment options. Cancer Res 2011:7137-7140.

-33 Bollag G, Hirth P, Tsai J, Zhang J, Ibrahim PN, Cho H, Spevak W, Zhang C, Zhang Y, Habets G, Burton EA, Wong B, Tsang G, West BL, Powell B, Shellooe R, Marimuthu A, Nguyen H, Zhang KY, Artis DR, Schlessinger J, Su F, Higgins B, Iyer R, D‘Andrea K, Koehler A, Stumm M, Lin PS, Lee RJ, Grippo J, Puzanov I, Kim KB, Ribas A, McArthur GA, Sosman JA, Chapman PB, Flaherty KT, Xu X, Nathanson KL, Nolop K: Clinical efficacy of a raf inhibitor needs broad target blockade in braf mutant melanoma. Nature 2010;467:596-599.

34 McMahon G: Vegf receptor signaling in tumor angiogenesis. Oncologist 2000;5:3-10.

-35 Taeger J, Moser C, Hellerbrand C, Mycielska ME, Glockzin G, Schlitt HJ, Geissler EK, Stoeltzing O, Lang SA: Targeting fgfr/pdgfr/vegfr impairs tumor growth, angiogenesis, and metastasis by effects on tumor cells, endothelial cells, and pericytes in pancreatic cancer. Mol Cancer Ther 2011;10:2157-2167. 


\section{Cellular Physiology and Biochemistry}

Cell Physiol Biochem 2013;32:138-153

\begin{tabular}{l|l}
\hline DOI: $10.1159 / 000350123$ & (C) 2013 S. Karger AG, Basel
\end{tabular}

Chen et al.: SC-535, a Multikinase Inhibitor, Anti-Melanoma

-36 Wilhelm SM, Carter C, Tang L, Wilkie D, McNabola A, Rong H, Chen C, Zhang X, Vincent P, McHugh M, Cao Y, Shujath J, Gawlak S, Eveleigh D, Rowley B, Liu L, Adnane L, Lynch M, Auclair D, Taylor I, Gedrich R, Voznesensky A, Riedl B, Post LE, Bollag G, Trail PA: Bay 43-9006 exhibits broad spectrum oral antitumor activity and targets the raf/mek/erk pathway and receptor tyrosine kinases involved in tumor progression and angiogenesis. Cancer Res 2004;64:7099-7109.

37 Dhomen N, Marais R: New insight into braf mutations in cancer. Curr Opin Genet Dev 2007;17:31-39.

- 38 Amaravadi RK, Schuchter LM, McDermott DF, Kramer A, Giles L, Gramlich K, Carberry M, Troxel AB, Letrero R, Nathanson KL, Atkins MB, O`Dwyer PJ, Flaherty KT: Phase ii trial of temozolomide and sorafenib in advanced melanoma patients with or without brain metastases. Clin Cancer Res 2009;15:7711-7718.

-39 Margolin KA, Moon J, Flaherty LE, Lao CD, Akerley WL $3^{\text {rd }}$, Othus M, Sosman JA, Kirkwood JM, Sondak VK: Randomized phase ii trial of sorafenib with temsirolimus or tipifarnib in untreated metastatic melanoma (s0438). Clin Cancer Res 2012;18:1129-1137.

40 Kaempgen E, Schmid M, Erdmann M, Keikavoussi P, Strobel D, Schuler-Thurner B, Schuler G: Predictable clinical responses to sorafenib in stage iv uveal melanoma. J Clin Oncol Abstr 2012;30.

-41 Panka DJ, Wang W, Atkins MB, Mier JW: The raf inhibitor bay 43-9006 (sorafenib) induces caspase-independent apoptosis in melanoma cells. Cancer Res 2006;66:1611-1619.

-42 Wang R, He G, Nelman-Gonzalez M, Ashorn CL, Gallick GE, Stukenberg PT, Kirschner MW, Kuang J: Regulation of cdc25c by erk-map kinases during the g2/m transition. Cell 2007;128:1119-1132.

-43 Samadi AK, Zhang X, Mukerji R, Donnelly AC, Blagg BS, Cohen MS: A novel c-terminal hsp90 inhibitor ku135 induces apoptosis and cell cycle arrest in melanoma cells. Cancer letters 2011;312:158-167.

44 Arozarena I, Sanchez-Laorden B, Packer L, Hidalgo-Carcedo C, Hayward R, Viros A, Sahai E, Marais R: Oncogenic braf induces melanoma cell invasion by downregulating the cgmp-specific phosphodiesterase pde5a. Cancer Cell 2011;19:45-57.

45 Lito P, Pratilas CA, Joseph EW, Tadi M, Halilovic E, Zubrowski M, Huang A, Wong WL, Callahan MK, Merghoub T, Wolchok JD, de Stanchina E, Chandarlapaty S, Poulikakos PI, Fagin JA, Rosen N: Relief of profound feedback inhibition of mitogenic signaling by raf inhibitors attenuates their activity in brafv600e melanomas. Cancer Cell 2012;22:668-682.

46 Montagut C, Sharma SV, Shioda T, McDermott U, Ulman M, Ulkus LE, Dias-Santagata D, Stubbs H, Lee DY, Singh A, Drew L, Haber DA, Settleman J: Elevated craf as a potential mechanism of acquired resistance to braf inhibition in melanoma. Cancer Res 2008;68:4853-4861.

-47 Dougherty MK, Muller J, Ritt DA, Zhou M, Zhou XZ, Copeland TD, Conrads TP, Veenstra TD, Lu KP, Morrison DK: Regulation of raf-1 by direct feedback phosphorylation. Mol Cell 2005;17:215-224. 